\title{
Constraints and Breeding Priorities for Increased Sweetpotato Utilization in Ghana
}

\author{
Ernest Baafi ${ }^{1}$, Joe Manu-Aduening ${ }^{1}$, Edward E. Carey $^{3}$, Kwadwo Ofori ${ }^{2}$, Essie T. Blay ${ }^{2} \&$ Vernon E. Gracen $^{2}$ \\ ${ }^{1}$ CSIR-Crops Research Institute, P. O. Box 3785, Kumasi, Ghana \\ ${ }^{2}$ West Africa Centre for Crop Improvement, University of Ghana, Legon \\ ${ }^{3}$ International Potato Centre (CIP), Ghana \\ Correspondence: Ernest Baafi, CSIR-Crops Research Institute, P. O. Box 3785, Kumasi, Ghana. Tel: \\ 233-244-155-180. E-mail: e.baafi@gmail.com
}

Received: May 25, 2015 Accepted: June 4, 2015 Online Published: July 7, 2015

doi:10.5539/sar.v4n4p1 URL: http://dx.doi.org/10.5539/sar.v4n4p1

\begin{abstract}
Sweetpotato is used in various food preparations in place of rice, cassava, yam and plantain in Ghana. In spite of this it does not have the same importance in Ghanaian diet as other root and tuber crops. Consumer taste, preference and acceptance are critical in determining the suitability of sweetpotato cultivars to any locality. A study was carried out in some selected communities of Ghana where sweetpotato is popular which span all five ecozones of Ghana in February, 2012. The main objective was to investigate why sweetpotato has low utilization compared with other root and tuber crops and to increase its utilization through breeding. The study employed Focus Group Discussion (FGD) followed by administration of Semi-structured Questionnaire (SSQ). Data collected were analysed using Genstat and Statistical Package for Social Sciences. Seventy-nine people consisting of $63 \%$ males and $37 \%$ females, and 178 people consisting of $52 \%$ female and $48 \%$ males were involved in the FGD and SSQ, respectively. Majority (94\%) of farmers' ranked sweetpotato from 1 to 5 among 24 cultivated crops. Only about $28 \%$ of consumers ate sweetpotato at least six days per week. The survey revealed that consumers in Ghana desired non-sweet, high dry matter sweetpotato cultivars. Therefore, there is need for Research and Development to adjust sweetpotato breeding objectives and selection procedures to develop high dry matter non-sweet sweetpotato varieties in Ghana.
\end{abstract}

Keywords: beta-carotene, breeding, dry matter, non-sweet, sweetpotato

\section{Introduction}

Sweetpotato (Ipomoea batatas, L) is one of the most important root crops in the world with more than 133 million tonnes produced worldwide annually (Warammboi et al., 2011). The crop has versatility in Ghana and is used in various food preparations in place of rice, cassava, yam, plantain and other staples (Ellis et al., 2001; Meludu et al., 2003; Zuraida, 2003). In spite of this it does not have the same importance in the Ghanaian diet as other root and tuber crops, such as yam, cassava or cocoyam (Adu-Kwarteng et al., 2002; Opare-Obisaw et al., 2000). Its production peaked during the late 1950s, after which there has been a gradual decline (Doku, 1984), despite giant strides made through breeding to release 13 high yielding and early maturing cultivars.

The decision to adopt a new cultivar is complexly related to field and yield performance as well as consumer taste acceptability (Sugri et al., 2012). Consumer taste, preference and acceptance are critical in determining the degree of suitability of sweetpotato cultivars to any locality (Kwach et al., 2010; Tomlins et al., 2004). Food preferences may vary among individuals, age groups, gender and sometimes cultures as well as geographical locations (Sugri et al., 2012). Traits to select during crop improvement depend on the target beneficiaries (Sugri et al., 2012). It is believed that some cultivars that have been released were not adopted because of lack of sufficient consideration of farmers' (Derera et al., 2006), and other stakeholders' preferences in the process of their development. Breeders often fail to consider the special preferences of farmers (Banziger \& Cooper, 2001; Toomey, 1999), possibly because they are unaware of them (Derera et al., 2006). Breeding programmes must therefore adjust breeding objectives and selection procedures to meet consumer needs. Effective breeding should be based on clear identification of stakeholders perceived constraints and preferences. These can be identified through participatory plant breeding (PPB), participatory varietal selection (PVS) (Gasura et al., 2008; Gibson et 
al., 2007) and/or participatory rural appraisal (PRA).

This survey was aimed at (1) documenting the role of sweetpotato in the farming and food systems of Ghana, (2) identifying utilization constraints and opportunities, (3) understanding the current patterns of sweetpotato consumption, and (4) establishing general baseline data for future impact assessment for sweetpotato production and utilization in Ghana.

\section{Materials and Methods}

The study was conducted using Focus Group Discussions (FGD) followed by administration of a Semi-Structured Questionnaire (SSQ) in February, 2012. Focus Group Discussion and Semi-Structured Interview are tools of PRA. Focus Group Discussion (FGD) is a form of group interview that capitalises on communication and interactions among participants in order to generate data (Kitzinger, 1995). The method is particularly useful for exploring people's knowledge and experiences and can be used to examine not only what people think but how they think and why they think that way (Kitzinger, 1995). Semi-Structured Interview is a powerful research tool that provides valuable spontaneous information that can be used for quantitative purposes, such as the testing of hypotheses or the generalisation of findings for larger areas.

\subsection{Study area}

The study was conducted in all the communities except Kumasi for the FGD (Table 1). These communities were the major sweetpotato production, marketing and utilization areas in Ghana, spanning over all five agroecological zones of Ghana. The areas covered latitude $4^{\circ} 30^{\prime}$ to $11^{\circ}$ north of the Equator, and longitudes $1^{\circ}$ $12^{\prime}$ 'east to $3^{\circ} 15^{\prime}$ 'west.

Table 1. List of study communities for the survey

\begin{tabular}{llll}
\hline Community & Metropolitan/District & Region & Ecozone \\
\hline Fiaso & Techiman & Brong Ahafo & Transition \\
*Kumasi & Kumasi & Ashanti & Forest \\
Komenda & KEEA & Central & Coastal savanna \\
Aseja & Fanteakwa & Eastern & Forest \\
Sege & Dangme East & Greater Accra & Coastal Savanna \\
Woriborgu-kukuo & Tolon & Northern & Guinea Savanna \\
Natugnia & Kassena-Nankana & Upper East & Sudan Savanna \\
Agorve & Ketu-North & Volta & Coastal Savanna \\
\hline
\end{tabular}

*Community where Focus Group Discussion was not done.

\subsection{Focus Group Discussions (FGD)}

\subsubsection{Nature of Participants for the FGD}

District Agricultural Extension agents (AEAs) were actively involved in the identification and selection of respondents through random sampling. Participants were selected from sweetpotato stakeholders, namely consumers, farmers, marketers, and processors. In all, 79 participants were involved. These included 50 males and 29 females (Table 2).

Table 2. Group characteristics of the focus group discussion

\begin{tabular}{llll}
\hline Region & Females & Males & Total \\
\hline Brong Ahafo & 2 & 6 & 8 \\
Central & 1 & 11 & 12 \\
Eastern & 8 & 4 & 12 \\
Greater Accra & 6 & 6 & 12 \\
Northern & 4 & 7 & 11 \\
Upper East & 4 & 8 & 12 \\
Volta & 4 & 8 & 12 \\
Total & 29 & 50 & 79 \\
\hline
\end{tabular}




\subsubsection{Focus Group Discussion Data Collection and Analysis}

The data were collected by a team composed of a facilitator/moderator and two recorders. In communities where language was a barrier, an interpreter was hired. An open-structured questionnaire guided by a checklist (variety grown, source of planting material, uses, gender, and farming systems) was used. General description of the group dynamics was also recorded. The data were converted to numerical values, standardized (Etzkorn, 2011), and analysed using Principal Component Analysis (PCA). The analyses were done using Genstat (Released 9.2.0.152) Computer package (Genstat, 2007).

\subsection{Administration of Semi-structured Questionnaire (SSQ)}

\subsubsection{Structure of Respondents for the Semi-structured Interview}

In all, 178 people involving $52 \%$ female and $48 \%$ males were interviewed. The structure of respondents is presented in Figure 1. There were 160 consumers of sweetpotato, 123 sweetpotato farmers, 40 sweetpotato traders and 18 sweetpotato processors. Among them were 24 traders who were also consumers, 93 farmers who were consumers, 11 people who were consumers and processors and one person who was a farmer and a trader. Out of the 178 respondents, 15, 12, 3 and 2 of the respondents were only consumers, farmers, traders, and processors, respectively. The number of respondents per community is presented in Table 3 .

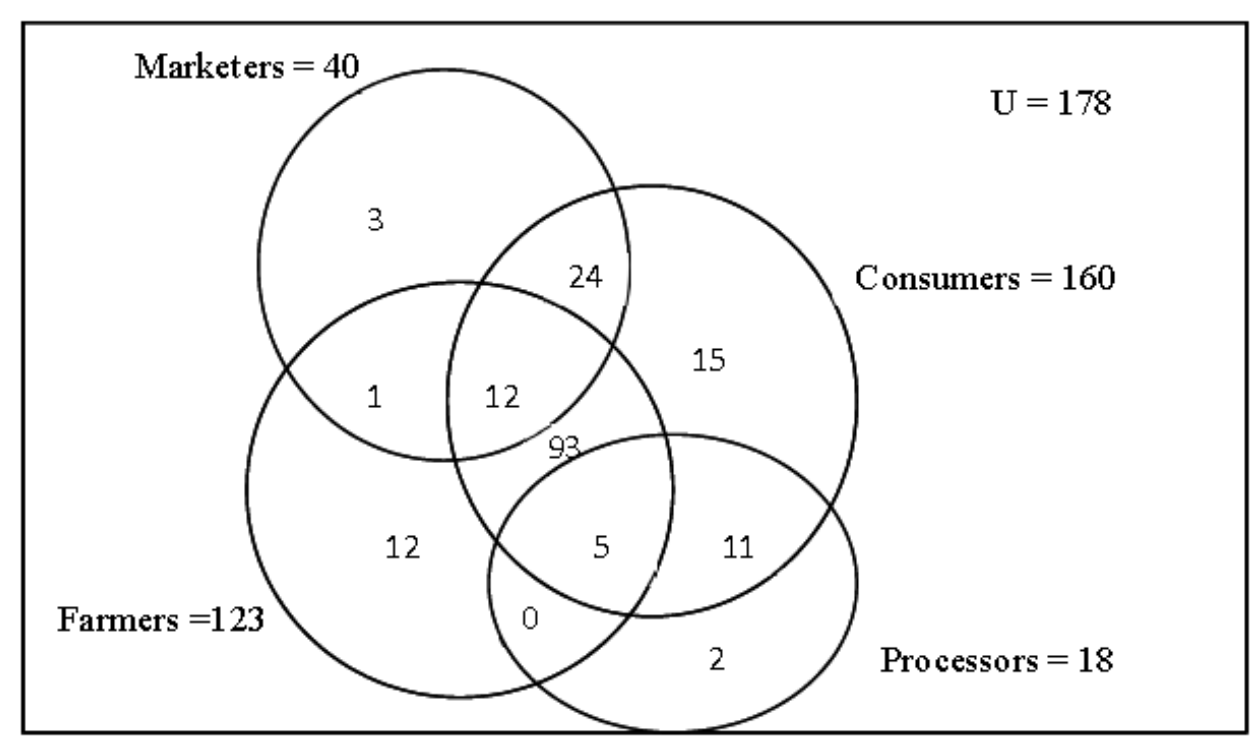

Figure 1. Euler diagram of respondents

\subsubsection{Semi-structured Questionnaire Data Collection and Analysis}

Interviews were used in the data collection. District Agricultural Extension Agents (AEAs) were involved in the identification and selection of respondents by random sampling. The Semi-structured Questionnaire (SSQ) was developed using a checklist which included gender, kind of stakeholder, crop enterprise, food consumption pattern, and sweetpotato preference. Sweetpotato root-flesh colour chart was used to estimate the beta-carotene content of the storage root. In the colour chart, white-flesh represented low beta-carotene content, yellow-flesh represented moderate beta-carotene content and orange-flesh represented high beta-carotene content. The interview was done as a follow-up to the FGD. Data were analysed using Statistical Package for Social Sciences (SPSS Release 16.0) Computer software (SPSS, 2007). Results were summarized into frequencies and percentages and represented in tables and graphs. 
Table 3. Frequency of respondents per community (Region) for the semi-structured interview

\begin{tabular}{lccc}
\hline \multirow{2}{*}{ Community (Region) } & \multicolumn{3}{c}{ Respondents } \\
\cline { 2 - 4 } & Number of participants & Percent & Cumulative Percent \\
\hline Ashanti & 13 & 7.3 & 7.3 \\
Brong Ahafo & 17 & 9.6 & 16.9 \\
Central & 28 & 15.7 & 32.6 \\
Great Accra & 19 & 10.7 & 43.3 \\
Upper East & 30 & 16.9 & 60.1 \\
Volta & 40 & 22.5 & 82.6 \\
Northern & 17 & 9.6 & 92.1 \\
Eastern & 14 & 7.9 & 100 \\
Total & 178 & 100.0 & \\
\hline
\end{tabular}

\section{Results}

\subsection{Role of Sweetpotato in Farming and Food Systems}

Fifteen variables (Table 4) were recorded during each session of the FGD. The first five principal components (PCs) with Eigen values greater than 1.0 together explained $96.33 \%$ of the total variation in the data set (Table 4). Scores for method of storage and emotional aspect of participants were not significantly associated with any of the Principal Components. Scores on the first two PCs accounted for $58.75 \%$ of the variation, and were related to all the variables except sex and source of planting material, which were related to PCs 3 and 5.

Table 4. Principal component analysis of the 15 variables recorded for the focus group discussion

\begin{tabular}{lccccr}
\hline Variables & PC1 & PC2 & PC3 & PC4 & PC5 \\
\hline Total participants & $\mathbf{- 0 . 3 2 7}$ & -0.080 & -0.200 & -0.191 & 0.437 \\
Sex & -0.148 & 0.048 & $\mathbf{0 . 5 9 9}$ & 0.037 & -0.243 \\
Crop calendar & $\mathbf{0 . 3 1 5}$ & 0.121 & -0.201 & 0.215 & $\mathbf{0 . 4 9 6}$ \\
Crop enterprise & $\mathbf{- 0 . 4 2 0}$ & -0.048 & -0.019 & 0.025 & 0.170 \\
Rank of sweetpotato & $\mathbf{- 0 . 3 0 3}$ & 0.200 & 0.063 & $\mathbf{- 0 . 4 7 4}$ & 0.114 \\
Variety grown & $\mathbf{- 0 . 3 2 5}$ & -0.225 & $\mathbf{- 0 . 3 7 7}$ & -0.026 & -0.119 \\
Planting material source & -0.234 & 0.171 & 0.270 & 0.034 & $\mathbf{0 . 4 9 4}$ \\
Source of sweetpotatoes eaten & $\mathbf{- 0 . 3 2 9}$ & 0.179 & $\mathbf{- 0 . 3 0 3}$ & $\mathbf{- 0 . 3 1 7}$ & -0.005 \\
Ways sweetpotato is eaten & 0.119 & $\mathbf{- 0 . 4 2 7}$ & 0.091 & $\mathbf{- 0 . 5 2 5}$ & 0.192 \\
Storage & 0.000 & 0.000 & 0.000 & 0.000 & 0.000 \\
Other uses & -0.079 & $\mathbf{- 0 . 3 0 5}$ & 0.288 & $\mathbf{0 . 5 1 5}$ & -0.200 \\
Constraints to consumption & 0.232 & $\mathbf{- 0 . 4 9 5}$ & -0.052 & 0.202 & 0.102 \\
Perception on health & -0.236 & $\mathbf{- 0 . 5 0 2}$ & 0.121 & -0.080 & 0.200 \\
Emotional aspect of participants & 0.000 & 0.000 & 0.000 & 0.000 & 0.000 \\
Group dynamics & $\mathbf{0 . 3 2 5}$ & 0.225 & $\mathbf{0 . 3 7 7}$ & 0.026 & 0.119 \\
Latent roots (Eigen values) & 5.183 & 2.454 & 2.198 & 1.518 & 1.170 \\
Variance (\%) & 39.87 & 18.88 & 16.91 & 11.67 & 9.00 \\
Cumulative (\%) & 39.87 & 58.75 & 75.66 & 87.33 & 96.33 \\
\hline
\end{tabular}

*Values in bold indicate the most relevant characters $(>0.3)$ that contributed most to the variation of the particular component.

The distribution produced by PCs 1 and 2 is shown in Figure 2. Brong Ahafo Region is separately classified in group 1, Volta and Eastern Regions are in group 2. Group 3 composed of Upper East and Central Regions while group 4 composed of Greater Accra and Northern Regions. 


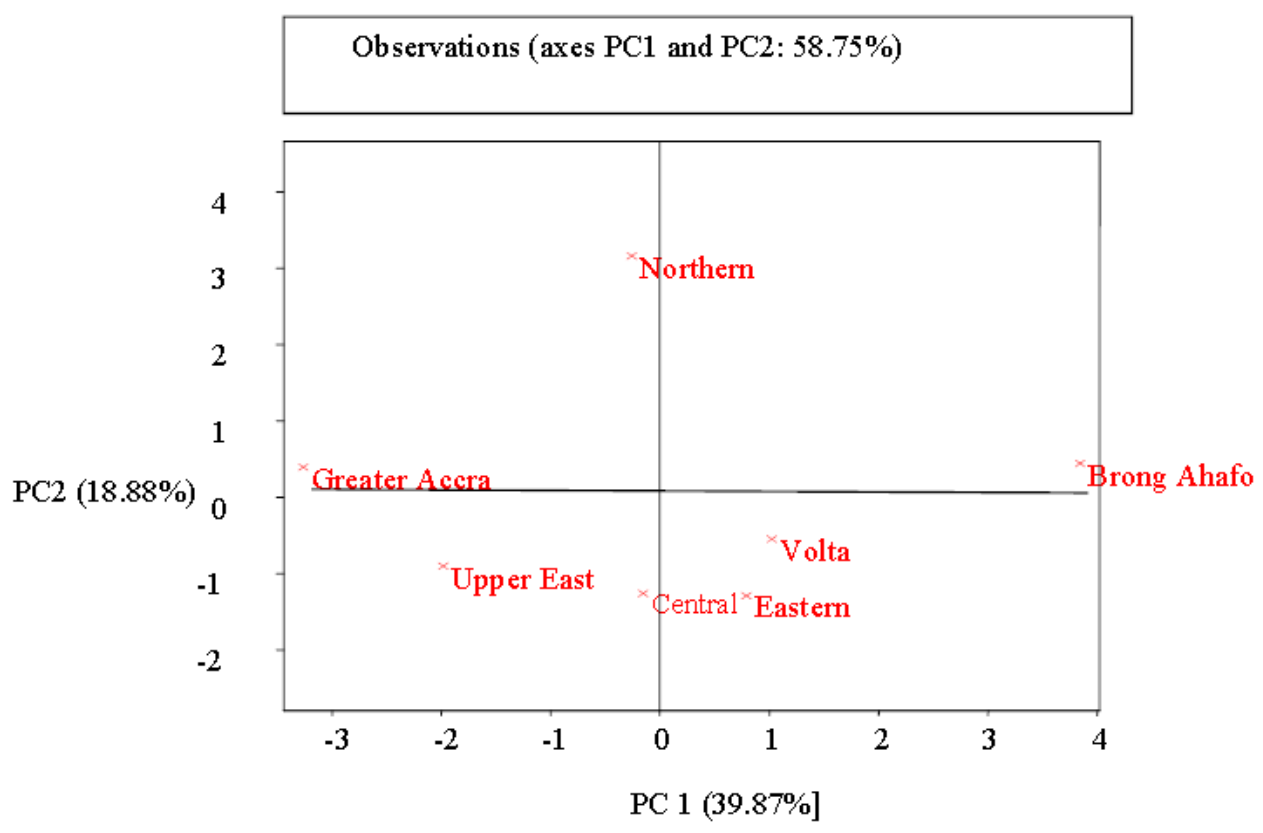

Figure 2. A biplot of PC1 and PC2 showing the distribution of communities involved in the focus group discussion

The hierarchical clustering (Figure 3) illustrates the relationship between responses among the communities. The communities were separated with Euclidean similarity distance from 1.00 to 0.75 . All the communities, except the Northern region, were similar at about 0.75 level of similarity. However, they were all distinct at 0.87 level. Four main clusters, A, B, C, and D, were identified at similarity level 0.76 . Cluster B was composed of the Volta and the Eastern Regions, while Brong Ahafo Region and the Northern Region were found in cluster A and D, respectively. Cluster C was composed of Central, Upper East and the Greater Accra Regions.

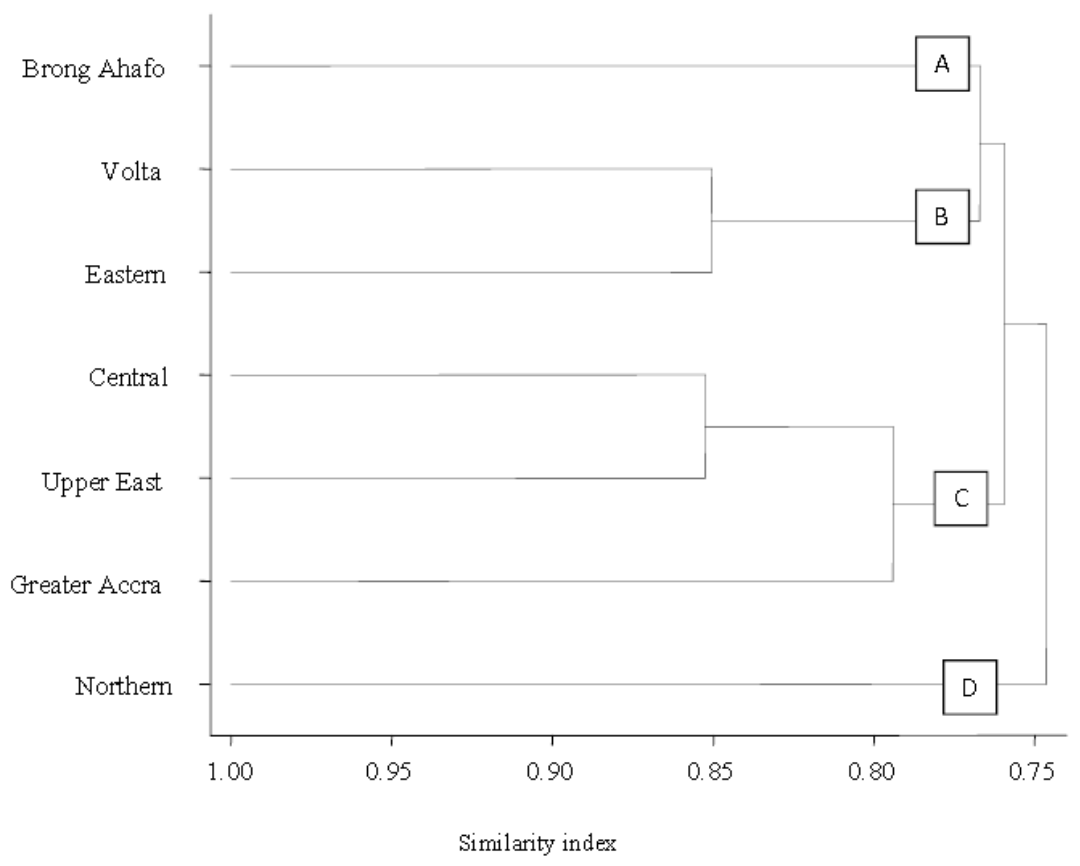

Figure 3. Dendrogram showing response of communities involve in the focus group discussion 


\subsubsection{Crop Enterprise of the Seven Communities Involved in the Focus Group Discussion}

In all, 24 crops were cultivated by the communities (Table 5). Brong Ahafo Region cultivated the least (9) whilst Greater Accra cultivated the highest (12). The crops cultivated includes roots and tubers (sweetpotato, cassava, yam, cocoyam and frafra potato), cereals (maize, millet and rice), legumes (cowpea, groundnut, bambara groundnut/beans and soybean), horticultural crops (tomato, okra, watermelon, onion, eggplant, cabbage, pepper and eggplant), and others - plantain, sugarcane and tiger nuts. Sweetpotato was ranked between first and tenth among the communities. It was ranked first in Brong Ahafo and Central Regions but, tenth in the Greater Accra Region.

Table 5. Crop enterprise ranking within the seven communities involved in the focus group discussion

\begin{tabular}{|c|c|c|c|c|c|c|c|}
\hline \multicolumn{8}{|l|}{ Region } \\
\hline Rank Position & Brong Ahafo & Central & Eastern & Greater Accra & Northern & Upper East & Volta \\
\hline 1 & Sweetpotato & Sweetpotato & Sweetpotato & Pepper & Maize & Millet & Maize \\
\hline 2 & Maize & Maize & Cassava & Tomato & Yam & Maize & Sugarcane \\
\hline 3 & Yam & Cassava & Maize & Cassava & Rice & Rice & Cassava \\
\hline 4 & Cassava & Watermelon & Plantain & Okra & Sweetpotato & Groundnut & Sweetpotato \\
\hline 5 & Watermelon & Tomato & Cocoyam & Maize & Cowpea & Sweetpotato & Rice \\
\hline 6 & Cowpea & Pepper & Pepper & Watermelon & Cassava & Frafra potato & Pepper \\
\hline 7 & Pepper & Okra & Yam & Cowpea & Groundnut & Bambara beans & Okra \\
\hline 8 & Egg plant & Egg plant & Tomato & Groundnut & Pepper & Cowpea & Tomato \\
\hline 9 & Onion & Groundnut & Okra & Egg plant & Soybean & Soybean & Groundnut \\
\hline 10 & & Tiger nut & Cowpea & Sweetpotato & Bambara groundnut & Pepper & Cowpea \\
\hline 11 & & Yam & & Cabbage & Tomato & Egg plant & \\
\hline 12 & & & & Onion & & & \\
\hline
\end{tabular}

\subsubsection{Farm Level Characteristics of Respondents Involved in the Semi-Structured Interviewing}

Sweetpotato was ranked from first to tenth among the 24 crops cultivated by the farmers. Out of the 123 farmers interviewed, about $94 \%$ ranked sweetpotato first to fifth, while about $32 \%$ ranked it as their first choice (Table 6). The majority of the farmers were engaged in sole cropping (92\%) as against $8 \%$ for intercropping. The area under cultivation ranged from 0.25 to 12.0 acres (Table 7). However, majority (about 92\%) of the farmers had sweetpotato farm sizes between 0.25 acres and 3.0 acres. Farmers cultivating one acre of land (25\%) were in the majority followed by those cultivating 2 acres $(20 \%)$.

Table 6. Relative ranking of sweetpotato among 24 cultivated crops by respondents

\begin{tabular}{cccc}
\hline Rank & $\begin{array}{c}\text { Number of farmers } \\
\text { interviewed }\end{array}$ & $\begin{array}{c}\text { Percent of farmers } \\
\text { interviewed }\end{array}$ & $\begin{array}{c}\text { Cumulative Percent of farmers } \\
\text { interviewed }\end{array}$ \\
\hline 1 & 39 & 31.7 & 31.7 \\
2 & 8 & 6.5 & 38.2 \\
3 & 23 & 18.7 & 56.9 \\
4 & 19 & 15.4 & 72.4 \\
5 & 26 & 21.1 & 93.5 \\
6 & 2 & 1.6 & 95.1 \\
7 & 1 & 0.8 & 95.9 \\
8 & 3 & 2.4 & 98.4 \\
9 & 1 & 0.8 & 99.2 \\
10 & 1 & 0.8 & 100 \\
Total & 123 & 100.0 & \\
\hline
\end{tabular}


Table 7. Frequency distribution of sweetpotato cropping land area

\begin{tabular}{cccc}
\hline Farm size (ac.) & Number of farmers interviewed & Percent of farmers interviewed & Cumulative Percent of farmers interviewed \\
\hline 0.25 & 21 & 17.1 & 17.1 \\
0.5 & 22 & 17.9 & 35.0 \\
0.75 & 1 & 0.8 & 35.8 \\
1 & 31 & 25.2 & 61.0 \\
1.25 & 1 & 0.8 & 61.8 \\
1.5 & 6 & 4.9 & 66.7 \\
2 & 25 & 20.3 & 87.0 \\
2.5 & 1 & 0.8 & 87.8 \\
3 & 5 & 4.1 & 91.9 \\
4 & 3 & 2.4 & 94.3 \\
5 & 2 & 1.6 & 95.9 \\
6 & 2 & 1.6 & 97.6 \\
7 & 1 & 0.8 & 98.4 \\
10 & 1 & 0.8 & 99.2 \\
12 & 1 & 0.8 & 100.0 \\
Total & 123 & 100.0 & \\
\hline
\end{tabular}

\subsection{Pattern of Sweetpotato Preferences and Utilization}

3.2.1 Demographics of Respondents Involved in the Semi-structured Interviewing

The lowest and highest number of respondents across the communities were 13 and 40 . These were from the Ashanti and the Volta Regions, respectively, and constitute about $7 \%$ and $23 \%$ of the total respondents. Fifty-two per cent of the respondents were 40 years of age and above compared to $47 \%$ and $1 \%$, respectively, for age classes 20-40 years and below 20 years (Figure 4). The educational background of respondents was distributed as follows; Primary or below $83 \%$ and High School and above, $17 \%$.

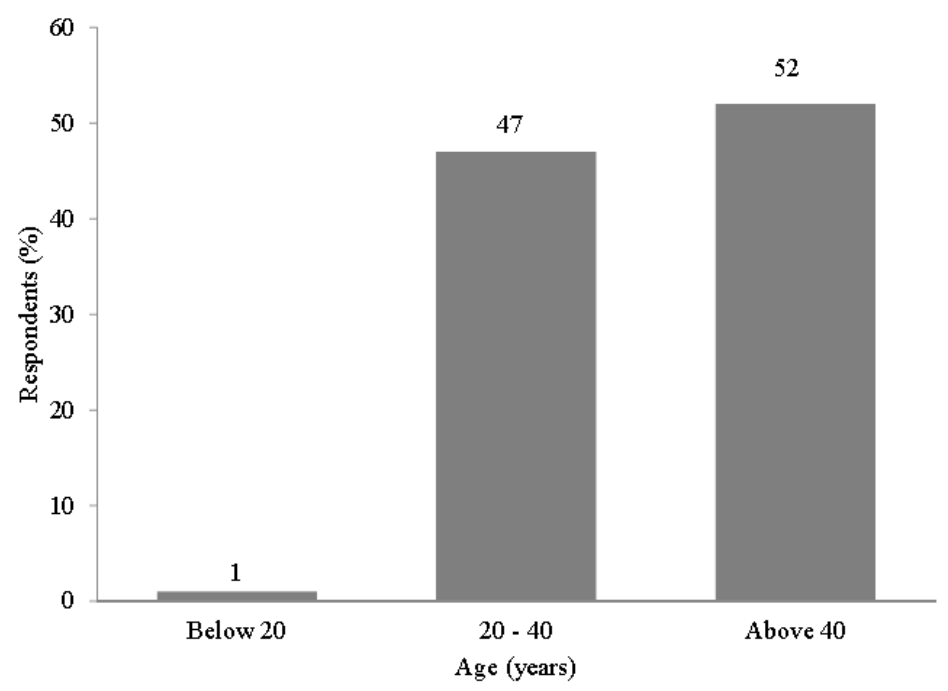

Figure 4. Age distribution of respondents involved in the semi-structured interviewing

\subsubsection{Sweetpotato Storage Root Utilization and Quality Preferences}

Sweetpotato utilization pattern is presented in Figure 5. About thirty-nine percent of consumers ate sweetpotato two or three days per week while about $28 \%$ consumed it at least six days per week and only about $12 \%$ of the respondents consuming sweetpotato at most only once a week. 


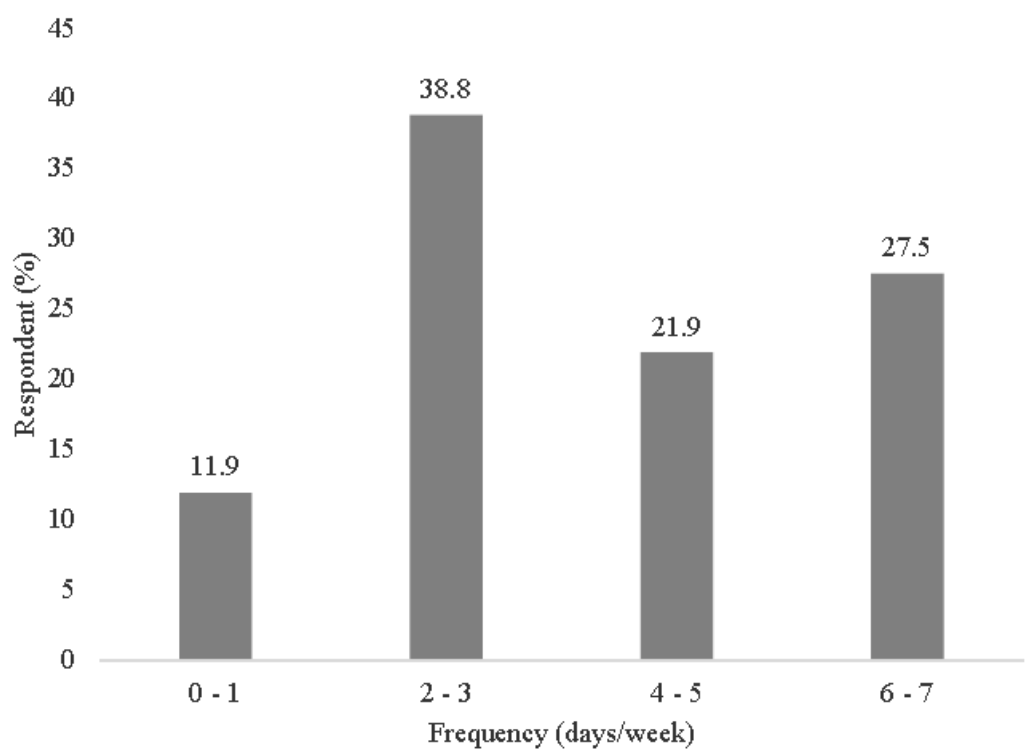

Figure 5. Sweetpotato consumption distribution for the respondents of the semi-structure questionnaire

Varietal preferences showed a response range from 7 to 138 respondents for the semantic differential scale (low, moderate, high, and any-type) for the storage root dry matter content (Figure 6). The lowest and highest values represent preference for any sweetpotato type and sweetpotato with high storage root dry matter content. Most respondents preferred high dry matter followed by moderate dry matter content while few preferred low dry matter content or didn't care. Most respondents (88) preferred moderate beta-carotene content (yellow-flesh) but 40 preferred low beta-carotene content (white-flesh) and 33 preferred high beta carotene content (Orange-flesh) while 17 had no preference for beta-carotene content (Figure 7). The results for the storage root taste (sweetness) are represented in Figure 8. The order of preference was less sweet (87), sweet (63), very sweet (25), and any-type (3), respectively. No significant interaction was observed between these storage root quality traits and age, educational background and sex of the respondents (Tables 8-11).

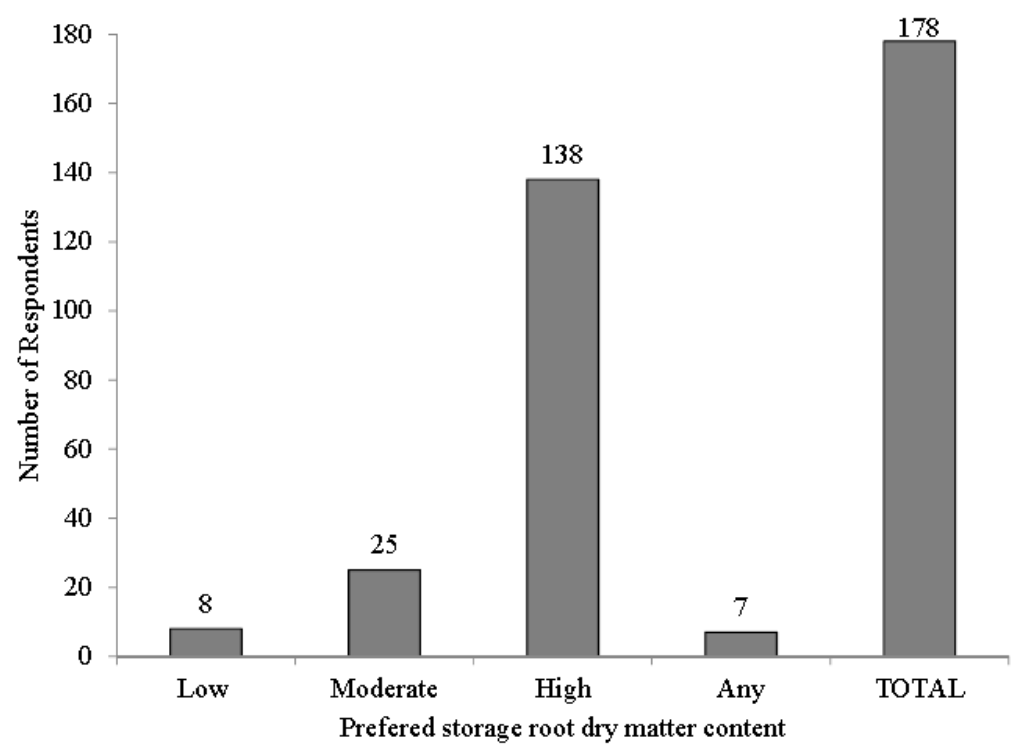

Figure 6. Preferred storage root dry matter content distribution for the respondents for the semi-structured questionnaire 


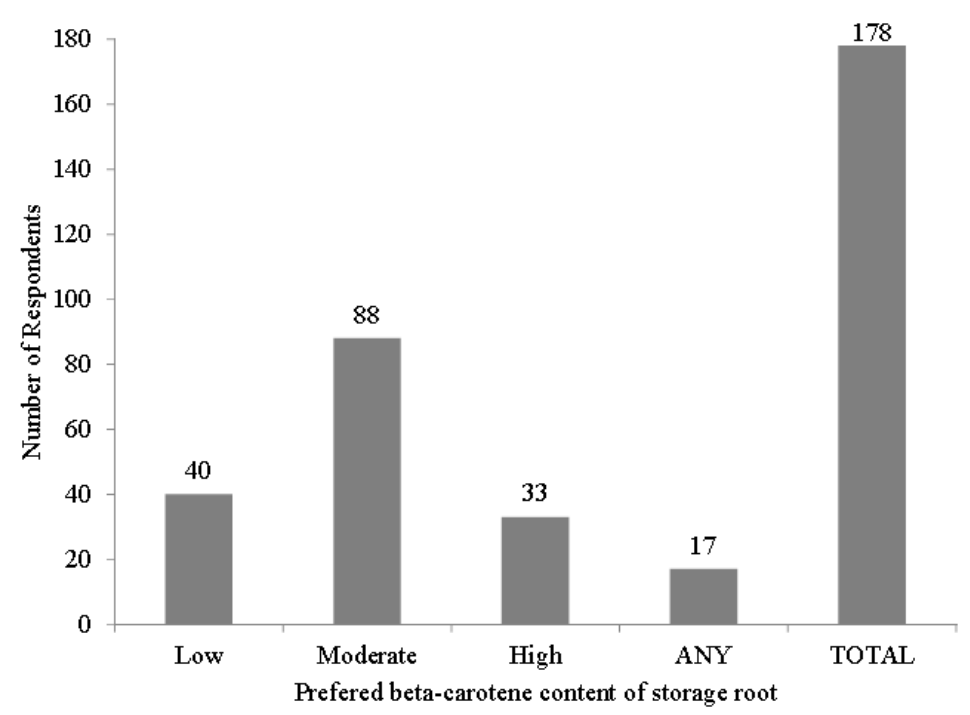

Figure 7. Distribution of preference for beta-carotene content of storage root for the respondents involved in the semi-structured interview

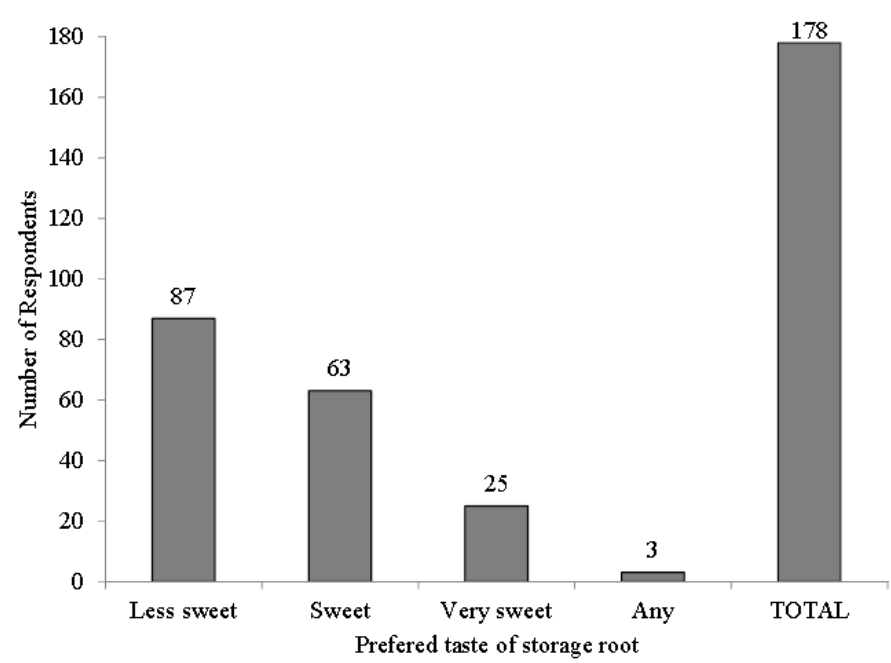

Figure 8. Storage root taste (sweetness) preference distribution for the respondents involved in the semi-structured interview

Table 8. Preference for beta-carotene and dry matter by different age groups of respondents

\begin{tabular}{lllllll}
\hline Trait & Age of Respondents & \multicolumn{5}{c}{ Preference } \\
\cline { 3 - 6 } & & Low & Moderate & High & Any & Total \\
\hline Beta-carotene & Below 20 & 0 & 0 & 0 & 2 & 2 \\
& $20-40$ & 15 & 48 & 14 & 7 & 84 \\
& Above 40 & 25 & 40 & 19 & 8 & 92 \\
& Total & 40 & 88 & 33 & 17 & 178 \\
Dry matter & & & & & & \\
& Below 20 & 0 & 0 & 2 & 0 & 2 \\
& 20-40 & 3 & 11 & 65 & 5 & 84 \\
& Above 40 & 5 & 14 & 71 & 2 & 92 \\
& Total & 8 & 25 & 138 & 7 & 178 \\
\hline
\end{tabular}


Table 9. Preference for beta-carotene and dry matter by different educational background of respondents

\begin{tabular}{lllllll}
\hline Trait & Respondents' Educational Background & \multicolumn{5}{c}{ Preference } \\
\cline { 3 - 6 } & & Low & Moderate & High & Any & Total \\
\hline Beta-carotene & Primary \& below & 35 & 63 & 33 & 17 & 148 \\
& High School \& above & 5 & 25 & 0 & 0 & 30 \\
& Total & 40 & 88 & 33 & 17 & 178 \\
\multirow{5}{*}{ Dry matter } & & & & & & \\
& Primary \& below & 6 & 20 & 117 & 5 & 148 \\
& High School \& above & 2 & 5 & 21 & 2 & 30 \\
& Total & 8 & 25 & 138 & 7 & 178 \\
\hline
\end{tabular}

Table 10. Beta-carotene and dry matter content preferences by sex of respondents

\begin{tabular}{lllllll}
\hline Trait & Sex of Respondents & \multicolumn{5}{c}{ Preference } \\
\cline { 3 - 6 } & & Low & Moderate & High & Any & Total \\
\hline Beta-carotene & Female & 23 & 48 & 13 & 8 & 92 \\
& Male & 17 & 40 & 20 & 9 & 86 \\
& Total & 40 & 88 & 33 & 17 & 178 \\
\multirow{5}{*}{ Dry matter } & & & & & & \\
& Female & 5 & 10 & 70 & 7 & 92 \\
& Male & 3 & 15 & 68 & 0 & 86 \\
& Total & 8 & 25 & 138 & 7 & 178 \\
\hline
\end{tabular}

Table 11. Taste (sweetness) preferences by different age groups, educational background and sex of respondents

\begin{tabular}{llllll}
\hline Source & \multicolumn{5}{c}{ Preference } \\
\cline { 2 - 6 } & Less sweet & Sweet & Very sweet & Any & Total \\
\hline AGE (years) & 0 & 0 & 1 & 1 & 2 \\
Below 20 & 37 & 30 & 17 & 0 & 84 \\
$20-40$ & 50 & 33 & 7 & 2 & 92 \\
Above 40 & 87 & 63 & 25 & 3 & 178 \\
Total & & & & & \\
EDUCATION & 74 & 52 & 19 & 3 & 148 \\
Primary \& below & 13 & 11 & 6 & 0 & 30 \\
High school \& above & 87 & 63 & 25 & 3 & 178 \\
Total & & & & & \\
SEX & 42 & 32 & 15 & 3 & 92 \\
Female & 45 & 31 & 10 & 0 & 86 \\
Male & 87 & 63 & 25 & 3 & 178 \\
Total & & & & & \\
\hline
\end{tabular}

There was preference for high root dry matter content across all the communities (Figure 9). Most communities also prefer moderate beta-carotene (yellow-flesh) sweetpotatoes (Figure 10). However, the Upper East Region and the Greater Accra Region preferred low beta-carotene (white-flesh) and high beta-carotene (orange-flesh) sweetpotatoes, respectively. The results show that the highest number of respondents preferred less sweet sweetpotatoes across the communities, with the exception of the Upper East Region where sweet types were rated highest (Figure 11). However, the proportion of respondents who preferred very sweet sweetpotato was quite substantial in the Volta Region. 


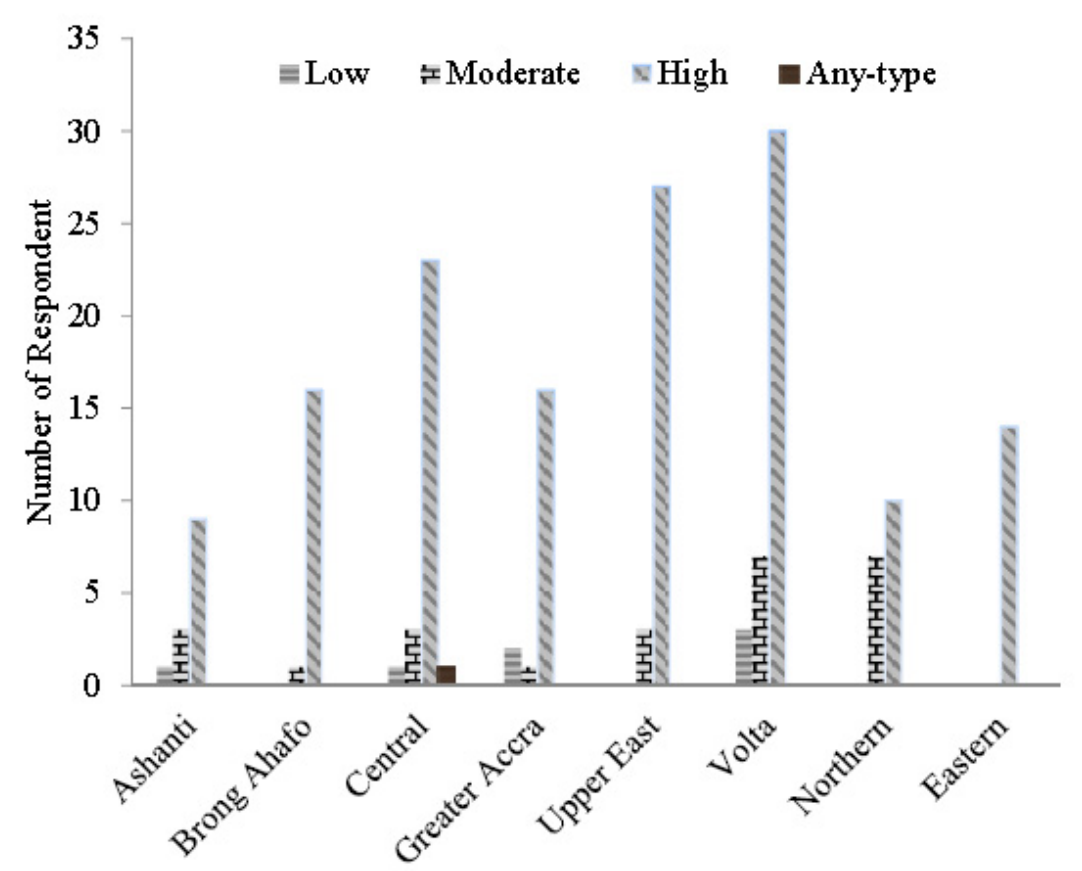

Figure 9. Respondents' preference for dry matter by different communities (Region)

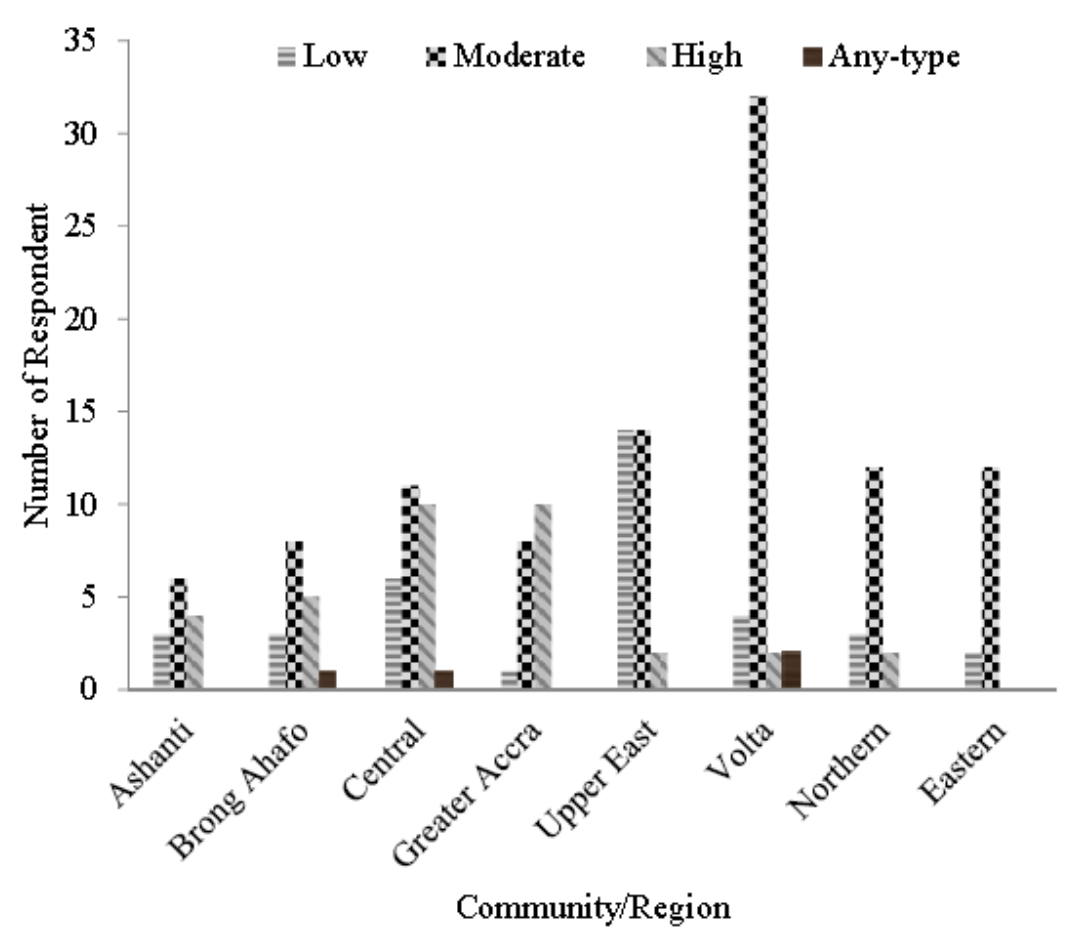

Figure 10. Respondents' preference for beta-carotene by different communities (Region) 


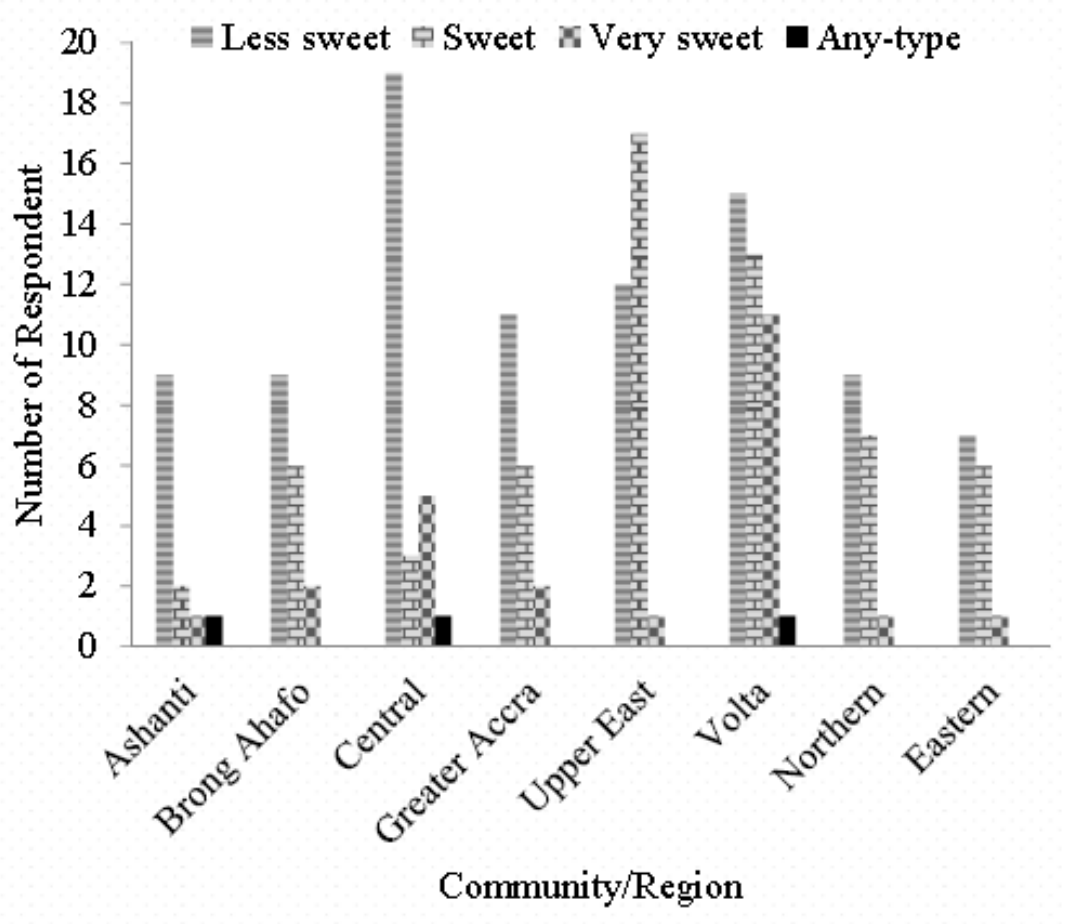

Figure 11. Respondents preference for storage root taste (sweetness) by different communities (Region)

\section{Discussion}

The variation obtained in 13 out of the 15 variables used for the Focus Group Discussion (FGD) suggests presence of a high degree of varying perception, knowledge and opinion for sweetpotato in Ghana. The level of interest and participation were very high, indicating that differences observed may be attributed to social background since discussions were held in different communities/regions. This is because; preference for sweetpotato varies with ethnic background and geographic location (Kays \& Horvat, 1983). For most communities sweetpotato is mainly grown and produced in one season (major cropping season) per year. The reason is the availability of rainfall and avoidance of the sweetpotato weevil. The sweetpotato weevil is the major pest of the crop worldwide especially in the drier agroecological zone (Ames et al., 1996; CIP, 1995). Major season plantings and harvestings are in March/April and August, respectively. Harvesting depends mainly on market availability and household demands. The decision on the crop grown was mainly based on food security and income generation. However, crop adaptability to the environment is also a critical factor in the Northern Region. The potential of sweetpotato as a food security and an income generation crop was confirmed by the current study. This is partly affirmed by the blend of stakeholders (farmers, consumers, processors, and marketers) identified to be associated with the crop. The relative ranking of sweetpotato to the other crops grown in the study area also affirms the food security and income generating potential of the crop. The average land holding for sweetpotato is very small compared to the other staple crops. This is because in most developing countries, sweetpotato is a smallholder crop tolerant to a wide range of edaphic and climatic conditions and grown with limited inputs (Lebot, 2010).

Stakeholders prefer sweetpotatoes with high storage root dry matter content because they suit their food preparation preferences. The method of cooking and the form of utilization have critical influence on taste and consumptive quality (Sugri et al., 2012). Sweetpotatoes were mainly consumed by frying or boiling in the form of ampesi. Cooking leads to changes in physical, sensory and chemical characteristics of the final product (Fontes et al., 2011; Vitrac et al., 2000). The storage root flesh is mainly starch, which swells upon water absorption which hydrolyses the weak bonds making it more easily digestible. However, low dry matter types lose their cooking quality (mealiness) when cooked, affecting textural characteristics preference. Frying enhances sensorial characteristics such as smell, flavour, colour, texture as well as overall palatability (Sugri et al., 2012). Frying involves drying, cooking or fast dehydration in which the water is removed from the food by means of immersion into oil at temperatures of $120-180{ }^{\circ} \mathrm{C}$ (Vitrac et al., 2000). The frying oil is incorporated 
into the food and occupies part of the space left by the evaporated water thereby increasing palatability, flavour, calorie supply and shelf-life (Fontes et al., 2011; Vitrac et al., 2000). For the reason that the oil occupies spaces left by water, low dry matter sweetpotatoes absorb more oil which is not economical to processors as well as healthy to the consumers. Other uses of sweetpotato were stew preparation from the leaves and as herb for jaundice (in the Eastern Region), and the use of the storage roots as a source of sugary flour for porridge in the Northern Region. One of the oldest uses was sweetening porridges and maize products, such as Aboolo (steamed or baked sweetened fermented maize dough) (Osei-Opare \& Adjei-Poku, 1977). The latter two may be exploited for commercial medicinal and sugar flour production.

There were varied responses for constraints to sweetpotato consumption. With exception of Greater Accra Region that did not have any constraint, the other communities mentioned sweetness as the major constraint that causes people to turn away from the crop as staple food. This affirms Missah and Kissiedu (1994) and Opare-Obisaw et al. (2000), who reported that locally available sweetpotatoes have very sweet taste, which limits their consumption as a staple food. It may also explain why it is uncommon to find sweetpotato served in Ghanaian restaurants, canteens, and schools unlike other roots and tubers which are widely consumed in a variety of preparations (Sam \& Dapaah, 2009). This confirms the report that high levels of sweetness and strong flavour associated with many cultivars of sweetpotatoes may have reduced its popularity as a staple food (Woolfe, 1992). The findings also agree with the observation that consumers in Ghana prefer sweetpotatoes with dry, mealy flesh and low sugar content (Sam \& Dapaah, 2009). The sweetness was perceived to have negative effect on health and was believed to cause diabetes, malaria, piles, flatulence, allergies, and hernia. These may also be the reasons why it is still not an important component of the average Ghanaian diet. These justify the need to adjust sweetpotato breeding objectives to develop non-sweet sweetpotato cultivars in Ghana to raise its standard to a staple food status. This is because according to Lebot (2010), although not thoroughly been investigated, the hundreds of sweetpotato cultivars found in Papua New Guinea and Island Melanesia, are low in sugar content, allowing an important daily consumption. Sweetpotato varieties that suit staple consumption must be non-sweet with sugar content less than $12 \%$ (Kays et al., 2005). Breeding such varieties is possible since a local variety of Vanuatu which suits staple purpose has a total sugar content as low as $1.49 \%$ of dry matter (Lebot et al., 2009).

In spite of these perceived hazards, good health attributes that were mentioned include better vision for children, and being good food for pregnant women. This suggests that the respondents have some knowledge of the benefit of beta-carotene found in the orange-flesh cultivars. Sweetpotatoes are used in a number of African countries to combat the widespread Vitamin A deficiency that results in blindness and/or death of 250,000 500,000 African children a year (CGIAR, 2005). However, preference for beta-carotene is skewed towards lowand moderate beta-carotene sweetpotatoes. Orange-flesh sweetpotato is not popular in Ghana even though it has been shown that even small amounts of these varieties as a regular part of the diet will eliminate vitamin A deficiency in adults and children. According to Thottappilly (2009), African countries have traditionally grown white-flesh sweetpotatoes which are low in vitamin A content. The orange-flesh cultivars are low in root dry matter content and high root dry matter content is preferred by most Ghanaians and this may be the reason for consumers' lack of preference for the orange-flesh types. However, considering the health benefits of the beta-carotene in the orange-fleshed types, it is important to incorporate high dry matter into the high beta-carotene genetic backgrounds. Dry matter content and beta-carotene content are negatively correlated (Baafi, 2014; Grüneberg et al., 2009), but this correlation can be broken by breeding and advance biotechnology. Crossing and recombination between superior, high beta-carotene and high dry matter parents, and selection among segregating progenies for improved performance is needed to develop superior new varieties. Recurrent selection increase the frequencies of favourable alleles at multiple loci in breeding populations through inter-mating of selected individuals (Moose \& Mumm, 2008). Recurrent selection could be used for the development of sweetpotatoes that have high dry matter content, high beta-carotene content and low sugar content (bland taste). There is also the need to educate consumers on their health concerns to ease their fears. This is because even though the galactoside oligosaccharides, verbascose, starchyose and raffinose in legumes have been correlated with their gas formation (flatulence) (Padmaja, 2009), there is no concrete evidence to that in sweetpotato (Truong et al., 1986). Again, despite its name sweetpotatoes may be a good food for diabetics as they help to stabilize blood sugar levels and provide lower insulin resistance (Kusano \& Abe, 2000; Ray \& Tomlins, 2010). They also need to be aware that sweetpotato consumption does not cause malaria. The high incidence of malaria is due to the widespread unclean environment which serves as the breeding grounds for the mosquitoes. Belief in such misinformation may also have accounted for why sweetpotatoes are not an important component of the average Ghanaian diet. 
Food preferences vary among individuals, age groups, gender and sometimes cultures as well as geographic locations (Sugri et al., 2012). A Preference for non-sweet sweetpotato cultivars with high storage root dry matter content was consistent across the entire respondents in this study. All of the communities preferred non-sweet high dry matter content sweetpotatoes. However, there were differences among the communities for preference for storage root beta-carotene content. Even though less sweet types were preferred in all the communities, consumers in the Upper East Region preferred moderately sweet types as well. The breeding objectives for developing and releasing sweetpotato in Ghana could be community specific. This is because preferences for the sweetpotato vary with ethnic background and geographic location (Kays \& Horvat, 1983).

\section{Conclusion}

This study was carried out to identify end-user constraints for sweetpotato utilization and to link the identifiable preferred traits to breeding for development of end-user preferred varieties for increased sweetpotato utilization in Ghana. The study was conducted using Focus Group Discussions (FGD) followed by administration of Semi-structured Questionnaire (SSQ). This study established the potential of sweetpotato as an income generating and food security crop in Ghana. It revealed very low utilization of sweetpotato in Ghana compared with the major root and tuber crops like cassava, yam and cocoyam. Very low patronage for sweetpotato in Ghana compared with the other root and tuber crops is due to lack of available end-user preferred sweetpotato cultivars that allow for daily consumption of the crop as staple food. The study revealed that consumers in Ghana desire non-sweet sweetpotatoes with high storage root dry matter content. There is a need for Research and Development to adjust sweetpotato breeding objectives and selection procedures to develop high dry matter non-sweet sweetpotato varieties in Ghana.

\section{Acknowledgements}

Many thanks to the Alliance for a Green Revolution in Africa (AGRA) for sponsoring this study. Thanks to the Director (Professor Eric Y. Danquah) and staff of West Africa Centre for Crop Improvement (WACCI), University of Ghana for your support. Thanks to my supervisors (Professors Vernon E. Gracen, Essie T. Blay, Kwadwo Ofori, Dr. Joe Manu-Aduening and Dr. Edward E. Carey) and staff of CSIR-Crops Research Institute, Fumesua, Ghana and the Ministry of Food and Agriculture, Ghana for your support.

\section{References}

Adu-Kwarteng, E., Otoo, J. A., Osei, C. K., \& Baning, I. S. (2002). Sweetpotato:The Crop of the Future. Factsheet Published by the Communications and Extension Division of Crops Research Institute - Council for Scientific and Industrial Research, Ghana.

Ames, T., Smit, N. E. J. M., Braun, A. R., O’Sullivan, J. N., \& Skoplund, L. G. (1996). Sweetpotato: Major Pest, Diseases, and Nutritional Disorders (p. 152). International Potato Center (CIP), Lima, Peru.

Baafi, E. (2014). Development of End-User Preferred Sweetpotato Varieties in Ghana. PhD Thesis. West Africa Centre for Crop Improbvemnt (WACCI), University of Ghana.

Banziger, M., \& Cooper, M. (2001). Breeding for Low Input Conditions and Consequences for Participatory Plant Breeding: Examples from Tropical Maize and Wheat. Euphytica, 122, 503-519. http://dx.doi.org/10.1023/A:1017510928038

CGIAR. (2005). FAOSTAT. Prodstat. Priorities and Strategies for Resource Allocation During 1998-2000 and Centre Proposals and TAC Recommendations. Retrieved June, 2010, from http://www.cgiar.org. Retrieved on 23/12/2010.

CIP. (1995). Sweetpotato / Sweetpotato Weevil. Retrieved from http://www.cgiar.org. Retrieved on 23/12/2010.

Derera, J., Tongoona, P., Langyintuo, A., Laing, M. D., \& Vivek, B. (2006). Farmer Perception on Maize Cultivars in the Marginal Eastern Belt of Zimbabwe and their Implications for Breeding. African Crop Science Journal, 14(1), 1-5.

Doku, E. V. (1984). The Sweet Potato, the Production and Uses. Legon Extension Bulletin No. 17 (pp. 1-13). Crop Science Department, University of Ghana, Legon.

Ellis, W. O., Oduro, I., Fianko, K., \& Otoo, J. A. (2001). Quality of Gari from Eighteen Sweetpotato Varieties. In Proceedings of the 8th ISTRC AB Symposium, Ibadan Nigeria, 2001. (pp. 146-50). Sweet Potatovarieties.

Etzkorn, B. (2011). Data Normalization and Standardization. Retrieved from

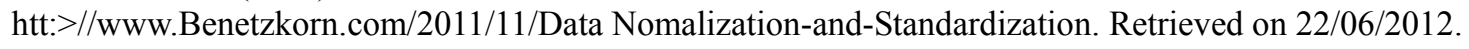

Fontes, L. C. B., Oliverira, F. G., \& Collares-Queiroz, F. P. (2011). Optimization of the Deep Fat Frying 
Processes of Sweetp otato Chips in Palm Olein or Stearin. American Jounal of Food Technology, 6, 348-361. http://dx.doi.org/10.3923/ajft.2011.348.361

Gasura, E., Mashingaidze, A. B., \& Mukasa, S. B. (2008). Genetic Variability for Tuber Yield, Quality, and Virus Disease Complex in Uganda Sweetpotato Germplasm. African Crop Science Journal, 16(2), 147-160.

Genstat. (2007). For Windows Release 9.2.0.152. Genstat-Ninth Edition@ 2007, Lowes Agricultural Trust.

Gibson, R. W., Byamukama, E., Mpembe, I., Kayongo, J., \& Mwanga, R. O. M. (2007). Working with Farmer Groups in Uganda to Develop New SweetPotato Cultivars: Decentralisation and Building on Traditional Approaches. Euphytica, 159, 217-228. Doi 10.1007/S10681-007-9477-4. Published Online: 4 July 2007. Springer Science+Business Media B.V. 2007.

Grüneberg, W., Robert, M., Maria, A., \& Harrison, D. (2009). Unleasing the Potential of Sweetpotato in Sub-Saharan Africa: Current Challenges and Way Forward. Challenge Them Paper 1: Sweetpotato Breeding. CIP - Social Sciences Working Paper 2009-1. (pp. 1 -42).

Kays, S. J., \& Horvat, R. J. (1983). A Comparison of the Volatile Constituents and Sugars of Representative Asian, Central American and North American Sweetpotatoes. (pp. 557-586). Sixth International Symposium on Tropical Root Crops, Lima, Peru.

Kays, S. J., Wang, Y., \& McLaurin, W. J. (2005). Chemical and Geographical Assessment of the Sweetness of the Cultivated Sweetpotato Clones of the World. Journal of the American Society for Horticultural Science, 130(4), 591-597.

Kitzinger, J. (1995). Quantitative Research: Introducing Focus Groups. British Medical Journal, 311(299). http://dx.doi.org/10.1136/bmj.311.7000.299

Kusano, S., \& Abe, H. (2000). Antidiabetic Activity of White Skinned Sweet Potato (Ipomoea Batatas L.) in Obese Zuckers Fatty Rats. Biological and Pharmaceutical Bulletin, 23, 23-26. http://dx.doi.org/10.1248/bpb.23.23

Kwach, J. K., Odhiambo, G. O., Dida, M. M., \& Gichuki, S. T. (2010). Participatory Consumer Evaluation of Twelve Sweetpotato Varieties in Kenya. African Journal Biotechnology, 9, 1600-1609.

Lebot, V. (2010). Sweet Potato. In J. E. Bradshaw (Ed.), Root and Tuber Crops, Handbook of Plant Breeding 7 , 97. http://dx.doi.org/10.1007/978-0-387-92765-7_3

Lebot, V., Champagne, A., Malapa, R., \& Shiley, D. (2009). NIR Determination of Major Constituents in Tropical Root and Tuber Crop Flours. Journal of Agricultural and Food Chemistry, 57, 10539-10547. http://dx.doi.org/10.1021/jf902675n

Meludu, N. T., Ajala, C. G., \& Akoroda, M. O. (2003). Poverty Alleviation through the Processing of Sweetpotato Tubers into Toasted Granules and Consumer Preferences in Nigeria. African Journal of Root and Tuber Crops, 5(2), 56-59.

Missah, A., \& Kissiedu, A. F. K. (1994). Effect of Time of Harvesting on the Yield and Pest Incidence of Two Sweet Potato Varieties in the Forest Zone of Ghana. In Proceedings of the 5th Symposium of ISTRC AB pp. 276-280.

Moose, S. P., \& Mumm, R. H. (2008). Molecular Plant Breeding as the Foundation for 21st Century Crop Improvement. Plant Physiology, 147(3), 969-977. http://dx.doi.org/10.1104/pp.108.118232

Opare-Obisaw, C., Danquah, A. O., Doku, E. V., Boakye, B. B., \& Ansah-Kissiedu, D. (2000). Consumer Evaluation of Five New Sweet Potato (Ipomea Batatas) Varieties. Journal of Consumer Studies \& Home Economics, 24, 61-65. http://dx.doi.org/10.1046/j.1365-2737.2000.00125.x

Osei-Opare, F., \& Adjei-Poku, C. (1977). SweetPotato Processing and Utilization (Theory and Practicals). Home Science Department, University of Ghana, Legon. 1-7.

Padmaja, G. (2009). Use and Nutritional Data of Sweetpotato. In The Sweetpotato. Edited by Gad Loebenstein and George Thottappilly. Springer Science+ Business Media B.V. 2009. http://dx.doi.org/10.1007/978-1-4020-9475-0_11

Ray, R. C., \& Tomlins, K. I. (2010). Sweetpotato: Post Harvest Aspects in Food, Feed and Industry, New York: Nova Science Publishers Inc.

Sam, J., \& Dapaah, H. (2009). West Afriican Agricultural Productiiviity Programme (WAAPP), Ghana Baseline Survey Report. October, 2009. (pp. 133). 
SPSS. (2007). Social Scientist Statistical Package for Windows Release 16.0. SPSS Inc. 1989 - 2007.

Sugri, I., Nutsugah, S. K., Wiredu, A. N., Johnson, P. N. T., \& Aduguba, D. (2012). Kendall's Concodance Analysis of Sensory Descriptors Influencing Consumer Preference for Sweetpotatoes in Ghana. American Journal of. Food Technology, 7(3), 142-150. http://dx.doi.org/10.3923/ajft.2012.142.150

Thottappilly, G. (2009). Introductory Remarks. In G. Loebenstein \& G. Thottappilly (Eds.), The Sweetpotato. (pp $1-7)$.

Tomlins, K., Rwiza, E., Nyango, A., Amour, A., \& Ngendello, T. (2004). The Use of Sensory Evalauation and Consumer Presference for the Selection of Sweet Potato Cultivars in East Africa. Journal of the Science of Food Agriculture, 84, 791-799.

Toomey, G. (1999). Farmer as Researchers: The Rise of Participatory Plant Breeding. International Development Research Centre, Ottawa, Canada.

Truong, V. D., Bierman, C. J., \& MarLelt, J. A. (1986). Simple Sugars, Oligosaccharides, and Starch Determination in Raw and Cooked Sweetpotato. Journal of Agricultural and Food Chemistry, 34(3), 421-425.

Vitrac, O., Trystam, G., \& Raoult-Wack, A. L. (2000). Deep-Fat Frying of Food: Heat and Mass Transfer, Transformations and Reactions inside the Frying Material. European Journal of Lipid Science and Technology, 102 , 529-538. http://dx.doi.org/10.1002/1438-9312(200009)102:8/9\%3C529::AID-EJLT529\%3E3.3.CO;2-6

Warammboi, J. G., Dennien, S., Gidley, M. J., \& Sopade, P. (2011). Characterization of Sweetpotato from Papua New Guinea and Australia: Physicochemical, Pasting and Gelatinisation Properties. Food Chemistry, 126, 1759-1770. http://dx.doi.org/10.1016/j.foodchem.2010.12.077

Woolfe, J. A. (1992). SweetPotato an Untapped Food Resource. Cambridge University Press, Cambridge.

Zuraida, N. (2003). Sweetpotato as an Alternative Food Supplement During Rice Shortage. Jurnal Litbang Pertanian, 22(4).

\section{Copyrights}

Copyright for this article is retained by the author(s), with first publication rights granted to the journal.

This is an open-access article distributed under the terms and conditions of the Creative Commons Attribution license (http://creativecommons.org/licenses/by/3.0/). 